\title{
Genetic relationships of Caribbean lowland spiny pocket mice (Heteromys desmarestianus: Rodentia; Heteromyidae): evidence of a distinct mitochondrial lineage
}

\author{
Andrea Romero ${ }^{*}$, Mark E. Mort ${ }^{2}$, J. Andrew DeWoody ${ }^{3}$, and Robert M. Timm² \\ ${ }^{1}$ Department of Biological Sciences and Department of Geography, Geology, and Environmental Science, University of Wisconsin- \\ Whitewater. 800 W Main St. Whitewater, WI 53190 U.S.A. Email: romeroa@gmail.com (AR). \\ ${ }^{2}$ Department of Ecology and Evolutionary Biology, University of Kansas. 1450 Jayhawk Blvd., Lawrence, KS 66045 U.S.A. Email: \\ memort@ku.edu (MEM), btimm@ku.edu (RMT). \\ ${ }^{3}$ Department of Biological Science and Department of Forestry \& Natural Resources, Purdue University. 610 Purdue Mall, West \\ Lafayette, IN 47907 U.S.A. Email: dewoody@purdue.edu (JAD). \\ *Corresponding author
}

\begin{abstract}
Genetic studies provide important insights into the evolutionary history and taxonomy of species, allowing us to identify lineages difficult to distinguish morphologically. The relationships among species in the genus Heteromys have been in flux as new species have been described, and candidate species have been suggested in the H. desmarestianus group. One new potential species may be in Costa Rica's Caribbean lowlands. Herein, we test the phylogenetic relationships of individuals from Costa Rica's Caribbean lowlands to individuals from throughout the species' range using mitochondrial sequences from cytochrome- $b$ (cytb). We captured 116 individuals from the lowlands, sequenced their cytb gene, and incorporated 74 GenBank sequences from throughout the species' range to test if individuals from Costa Rica's Caribbean lowlands potentially constitute an undescribed species. Our results document a distinct mitochondrial lineage in the Caribbean lowlands of Costa Rica. Our results from extensive sampling within the lowlands show a unique mitochondrial DNA lineage, which suggests the presence of an undescribed species. The Caribbean lowlands of Costa Rica may hold other cryptic diversity, and further phylogenetic studies should incorporate samples from this area, as it may have a unique evolutionary history.
\end{abstract}

Los estudios genéticos proporcionan información importante sobre la historia evolutiva y la taxonomía de las especies, lo que nos permite identificar linajes difíciles de distinguir morfológicamente. Las relaciones filogenéticas entre las especies del género Heteromys han estado cambiando a medida que se han descrito nuevas especies y se han sugerido especies candidatas en el grupo $H$. desmarestianus. Una nueva especie potencial podría encontrarse en las tierras bajas del Caribe de Costa Rica. En este trabajo analizamos las relaciones filogenéticas entre individuos de las tierras bajas del Caribe de Costa Rica con individuos de todo el rango de la especie utilizando secuencias mitocondriales del citocromo-b (cytb). Capturamos 116 individuos de las tierras bajas, secuenciamos su gen cytb e incorporamos 74 secuencias GenBank de todo el área de distribución de la especie para probar si los individuos de las tierras bajas del Caribe de Costa Rica constituyen potencialmente una especie no descrita. Nuestros resultados indican la presencia de un linaje distinto basado en el ADN mitocondrial, que sugiere que los individuos de las tierras bajas del Caribe de Costa Rica probablemente son una especie distinta. Las tierras bajas del Caribe de Costa Rica pueden tener una diversidad críptica significativa. Por ello sugerimos que estudios filogenéticos adicionales deberían incorporar muestras de esta área, ya que puede tener una historia evolutiva única.

Key words: Central America; cryptic species; cytochrome b; Heteromyidae; species boundaries.

@ 2019 Asociación Mexicana de Mastozoología, www.mastozoologiamexicana.org

\section{Introduction}

Understanding the relationships among evolutionary lineages is critical to estimating species diversity at varying spatial scales, reconstructing the evolutionary history of taxa, delineating ecological communities, and in making informed conservation decisions (Crozier 1992; Faith 1992; Crandall et al. 2000; Sinclair et al. 2005; Chave et al. 2007). Molecular data are increasingly used for evaluating relationships among species, identifying potential specieslevel clades, and identifying so-called cryptic species and thus can have significant impact on our understanding of evolutionary relationships (Sinclair et al. 2005; Beheregaray and Caccone 2007; Bickford et al. 2007; Mort et al. 2015).

With the continual improvement of molecular techniques and analyses, and broader sampling of natural populations, our understanding of phylogenetic relationships is often in flux. A group that has proven particularly difficult to delineate with traditional morphological characters are the species of spiny pocket mice of the genus Heteromys (Rodentia: Heteromyidae; see Anderson 2015 and references therein). Goldman (1911), in the first revision of the genus, recognized 13 species of Heteromys dividing them into two subgenera: Heteromys containing 12 species and Xylomys with a single species. This author further recognized the subgenus Heteromys as comprising two distinct species groups with the $H$. desmarestianus group containing eight species, including the first named Heteromys and most widely distributed species, $H$. desmarestianus (Gray, 1868). Recent research based on mitochondrial DNA indicates, however, that the lowland dry forest spiny pocket mice that were long recognized as a separate and sister genus, Liomys, are paraphyletic with respect to the species 
of Heteromys, thus should either be recognized as species of Heteromys or as another generic level clade (see Anderson et al. 2006; Hafner et al. 2007; Anderson and Gutiérrez 2009; and references therein). The current trend is to consider all species as belonging in the genus Heteromys.

Heteromys desmarestianus has remained a recognized taxon through several revisions (Hall 1981; Rogers and Schmidly 1982; Williams et al. 1993; Patton 2005; Rogers and González 2010), although new species have since been recognized (Anderson and Jarrín-V 2002; Anderson 2003; Anderson and Timm 2006; Anderson and Jansa 2007; Anderson and Gutiérrez 2009). Recently, Rogers and González (2010) suggested four additional clades within $H$. desmarestianus should be recognized. This research focuses on one of those four proposed clades that is located within the Caribbean lowlands of Costa Rica.

Heteromys desmarestianus, as currently defined, is common and widespread, ranging from southern Mexico to Colombia (Reid 2009). This species is found in evergreen and semideciduous forests, from sea level to high elevation cloud forests (Timm et al. 1989; Reid 2009). In Central America's Caribbean lowlands, the forest spiny pocket mouse is difficult to study because populations are often found at low densities (Fleming 1974; Timm et al. 1989), and anthropogenic disturbances often have negative impacts on density and species diversity (Romero, pers. obs.). Based on molecular evidence from mitochondrial and nuclear DNA of three individuals from Caribbean lowlands of Costa Rica, Rogers and González (2010) suggested that these individuals may actually represent a separate species from what is recognized as $\mathrm{H}$. desmarestianus. Herein, we test across multiple sites in the lowlands, if individuals from the Caribbean lowlands of Costa Rica are genetically distinct from what is recognized as $H$. desmarestianus and how this population(s) and others of the $H$. desmarestianus species complex are related to each other. In order to build a better understanding of the species diversity in this lineage and to test the hypothesis that there is greater diversity than is currently recognized we, herein, evaluate the relationship within the lineage currently recognized as the species $H$. desmarestianus.

\section{Materials and methods}

We trapped mice in several locations throughout the Caribbean lowlands of Costa Rica from 2007-2010 (Figure 1, Table 1). The Caribbean lowlands have similar ambient temperature throughout, but annual precipitation can vary from 2,400 to 4,800 mm per year (McClearn et al. 2016). Our localities (Table 1) ranged in elevation and size of forested area; our individuals from the highest elevation were from the Berlin property (Destierro) ranging from 210 to 280 masl. Samples from Berlin also represented our southernmost sample. Our northern-most samples were from the Refugio Nacional de Vida Silvestre Mixto Maquenque, close to the Costa Rica-Nicaragua border on the Río San Juan (Figure 1).

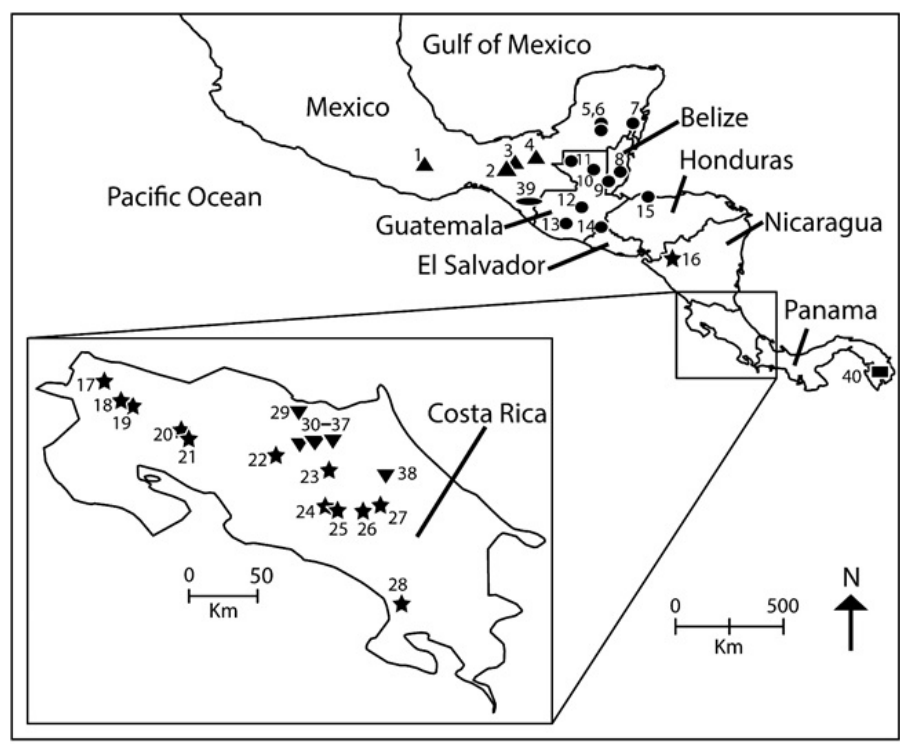

Figure 1. Map of localities for all specimens used in the study. Localities 29-38 represent specimens from Costa Rica's Caribbean lowlands. Symbols correspond to lineages depicted in the maximum likelihood tree (Figure 2). H. anomalus from Venezuela not depicted herein. Specific data regarding localities can be obtained from Appendix 1.

We used Sherman live traps $(8 \mathrm{~cm} \times 9 \mathrm{~cm} \times 23 \mathrm{~cm} ; \mathrm{H}$. B. Sherman Traps, Inc., Tallahassee, FL) placed at ground level and baited with cracked corn, oats, and mixed bird seed. Traps were checked daily, and when an individual was caught, a toe was removed with surgical scissors and immediately placed in $95 \%$ ethanol. All vials with tissue and ethanol were stored frozen within hours of collection. Voucher specimens of both complete specimens and toe samples are deposited at the University of Kansas Natural History Museum, Lawrence, Kansas. This project was undertaken with the approval of the University of Kansas Institutional Animal Care and Use Committee. All animal handling protocols were in accordance with the guidelines of the American Society of Mammalogists (Sikes et al. 2016).

Laboratory procedures - 116 samples from 10 sites in the Caribbean lowlands were used (Table 1) for genetic comparisons. Tissues were soaked in deionized water for one hr prior to beginning the digestion process. Standard digestion and DNA extraction were conducted following the protocol for mouse tails in Sambrook et al. (1989). The mitochondrial

Table 1. Sampling areas in the Caribbean lowlands of Costa Rica. Locality numbers refer to numbers from Figure 1.

\begin{tabular}{lrrrr}
\hline \multicolumn{1}{c}{ Site (locality) } & $\begin{array}{c}\text { Max elevation } \\
(\mathrm{m})\end{array}$ & $\begin{array}{c}\text { Min elevation } \\
(\mathrm{m})\end{array}$ & Latitude & Longitude \\
\hline Maquenque (29) & 70.1 & 47 & $10^{\circ} 40^{\prime} 48.96^{\prime \prime} \mathrm{N}$ & $-84^{\circ} 10^{\prime} 39.65^{\prime \prime} \mathrm{W}$ \\
Water Tower (34) & 98 & 42 & $10^{\circ} 27^{\prime} 52.90^{\prime \prime} \mathrm{N}$ & $-84^{\circ} 00^{\prime} 29.47^{\prime \prime} \mathrm{W}$ \\
Agrícola Sofía (35) & 68.58 & 51.21 & $10^{\circ} 27^{\prime} 32.01^{\prime \prime} \mathrm{N}$ & $-83^{\circ} 58^{\prime} 41.40^{\prime \prime} \mathrm{W}$ \\
Juan Enriques (31) & 189.59 & 45.72 & $10^{\circ} 27^{\prime} 20.46^{\prime \prime} \mathrm{N}$ & $-84^{\circ} 04^{\prime} 01.70^{\prime \prime} \mathrm{W}$ \\
Selva Verde (30) & 164.59 & 84.43 & $10^{\circ} 26^{\prime} 46.36^{\prime \prime} \mathrm{N}$ & $-84^{\circ} 04^{\prime} 00.62^{\prime \prime} \mathrm{W}$ \\
Starky (36) & 69 & 43 & $10^{\circ} 26^{\prime} 31.73^{\prime \prime} \mathrm{N}$ & $-83^{\circ} 59^{\prime} 09.16^{\prime \prime} \mathrm{W}$ \\
Fragment A (37) & 162 & 131 & $10^{\circ} 26^{\prime} 03.92^{\prime \prime} \mathrm{N}$ & $-84^{\circ} 07^{\prime} 42.76^{\prime \prime} \mathrm{W}$ \\
La Selva (32) & 146 & 22 & $10^{\circ} 25^{\prime} 47.90^{\prime \prime} \mathrm{N}$ & $-84^{\circ} 00^{\prime} 55.15^{\prime \prime} \mathrm{W}$ \\
Tirimbina (33) & 224.03 & 149.35 & $10^{\circ} 24^{\prime} 45.58^{\prime \prime} \mathrm{N}$ & $-84^{\circ} 07^{\prime} 02.55^{\prime \prime} \mathrm{W}$ \\
Berlin (38) & 280 & 210 & $10^{\circ} 07^{\prime} 59.73^{\prime \prime} \mathrm{N}$ & $-83^{\circ} 36^{\prime} 18.38^{\prime \prime} \mathrm{W}$ \\
\hline
\end{tabular}


cytochrome- $b$ (cytb) gene was amplified in full using the primers 765 and 766 (Bickham et al. 2004). Polymerase chain reaction (PCR) was performed using $50 \mu \mathrm{l}$ reactions of the following reagents: $5 \mu$ l of $10 \times$ buffer, $5 \mu$ l of $10 \times \mathrm{MgCl}_{2^{\prime}} 5 \mu \mathrm{l}$ of $10 \times$ solution of dNTP, $0.5 \mu$ l of Taq DNA polymerase, $5 \mu \mathrm{l}$ of a $10 \times$ solution of each primer, $25 \mu \mathrm{l}$ of deionized water, and $1-2 \mu$ l of extracted DNA. Thermal cycle conditions consisted of initial heating at $94^{\circ} \mathrm{C}$ for $3 \mathrm{~min}$, then 36 cycles of denaturation at $94^{\circ} \mathrm{C}$ for $30 \mathrm{~s}$, annealing at $50^{\circ} \mathrm{C}$ for $30 \mathrm{~s}$, and extension at $70^{\circ} \mathrm{C}$ for $2.5 \mathrm{~min}$. PCR products were purified using the QiAquick PCR purification kit (Qiagen, Valencia, CA) and were subsequently used in standard sequencing reactions using Big Dye version 3.0 (Applied Biosystems, Foster City, $C A)$. Sequencing reactions were cleaned using Sephadex spin columns and analyzed with an ABI 3100 automated genetic analyzer (Applied Biosystems, Forster City, CA). Sequence data were manually aligned using Sequencher $v$. 4.9 (Gene Codes Corporation, Ann Arbor, MI). We used the complete cytb gene, and all flanking regions were discarded prior to phylogenetic analysis.

To expand our dataset, we used cytb sequences of $H$. desmarestianus available from GenBank (Benson et al. 2013). We incorporated 74 individuals representing samples from throughout the range of the species, including specimens from near the type locality of $H$. desmarestianus, Cobán, Guatemala. Heteromys anomalus, H. australis, and H. nelsoni were used as outgroups (Appendix 1). We aligned all sequences with Muscle v.3.8.31 (Edgar 2004) implemented in Jalview 2.8 (Waterhouse et al. 2009).

Phylogenetic analysis-Phylogenetic relationships were obtained by performing a maximum likelihood (ML) analysis. We estimated models of molecular evolution using jModelTest v.2.1.1 with the corrected Akaike information criterion test (Guindon and Gascuel 2003; Darriba et al. 2012). We used GARLI v. 2.0 (Zwickl 2006) for ML analyses, using two independent search runs, with a maximum of five million generations each. Support values were calculated using bootstrap with 500 replications in GARLI, and results visualized and edited in FigTree v.1.4 (Rambaut 2007).

\section{Results}

The aligned data set comprises 1,142 characters of which 738 were constant, 335 characters were parsimony-informative, and 69 variable characters were parsimony-uninformative. The model of DNA substitution inferred from jModeltest 2.1.1 is TIM2+I+G.

The ML tree topology (Figure 2) shows two highly supported lineages for all individuals currently considered $H$. desmarestianus. One clade comprises all samples from the Caribbean lowlands of Costa Rica and had very strong (99 $\%)$ bootstrap support. The other lineage comprises all of the $H$. desmarestianus sequences obtained from Belize, Costa Rica (in part), El Salvador, Guatemala, Honduras, México, and Nicaragua and also have strong bootstrap support (83\%). Within the clade containing samples from the Caribbean lowlands of Costa Rica (not shown in Figure 2), the individuals from two sites, Berlin and Maquenque, formed clades supported by strong bootstrap support (90 $\%$ and $86 \%$, respectively). Two individuals from the eight sampled at Maquenque were placed elsewhere within the tree, and thus the nonexclusive nature of the branching pattern complicates lower level population patterns from these data. Maquenque is biologically quite interesting being in the floodplain of the Río San Juan and our continued studies there are elucidating other unexpected patterns with other rodent species.

Specimens collected near Baja Verapas, Guatemala (GU646966, GU646967, GU646968; Appendix) 30 km from the type locality, Cobán, cluster with specimens from Belize, El Salvador, Honduras, and parts of México, but not with specimens from the Caribbean lowlands of Costa Rica (Figure 2). The specimen that clustered closest to Cobán from our Costa Rican lowland dataset was from the Costa Rica-Nicaragua border region $\sim 850 \mathrm{~km}$ away. Genbank accession numbers of new sequences are reported in the Appendix.

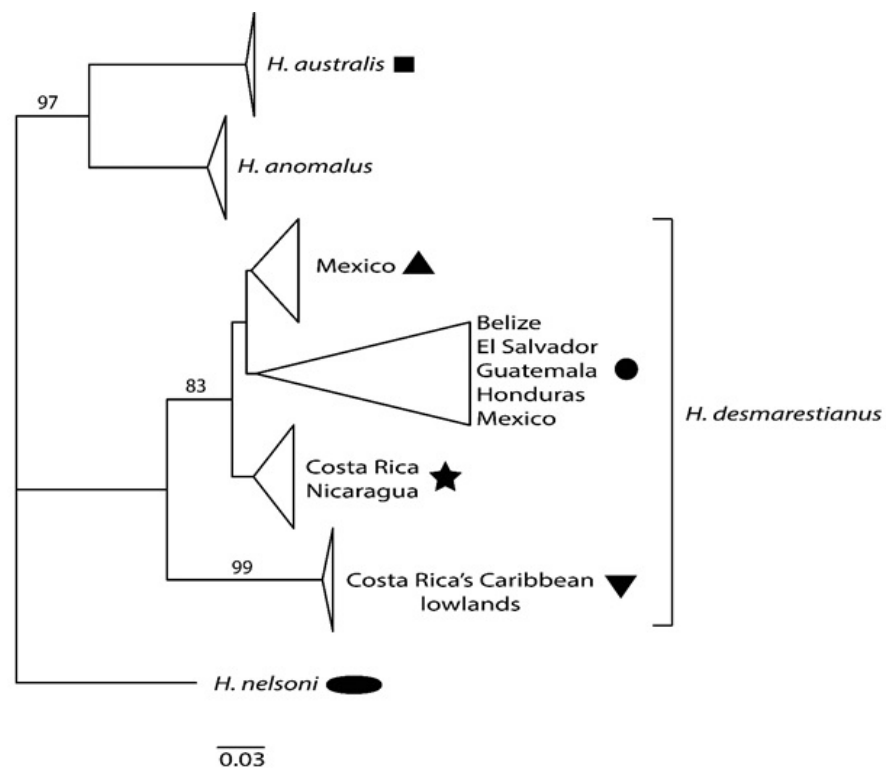

Figure 2. Maximum likelihood tree of our Heteromys dataset, based on cytb sequences. The maximum likelihood tree is collapsed for visual clarity, and shows the results with bootstrap values. These results indicate that individuals from Costa Rica's Caribbean lowlands harbor unique mitochondrial lineages that could reflect reproductive isolation. Symbols in tree are used in Figure 1 to show the geographic range of lineages. Tree is rooted with $H$. golmani.

\section{Discussion}

The results of this study strongly support the hypothesis that what is currently called Heteromys desmarestianus in Central America and northern-most South America comprises two very distinct clades, one being found in the Caribbean lowlands of Costa Rica and the other comprising all other populations. Our results show a clear geographic pattern; individuals currently considered $H$. desmarestianus in the Caribbean lowlands of Costa Rica harbor distinct mtDNA haplotypes from individuals considered $\mathrm{H}$. desmarestianus found elsewhere in the Neotropics, including other 
areas in Costa Rica (Figure 2). The specimens from near the type locality of $H$. desmarestianus, Cobán, Guatemala form a well-supported clade with specimens from southern México, Belize, El Salvador, and Honduras. Specimens from western Costa Rica and one specimen from western Nicaragua all form another distinct clade.

Costa Rica is only $\sim 51,000 \mathrm{~km}^{2}$, yet its variable topography and climate result in diverse habitats with unique flora and fauna (Janzen 1983). Currently, four main mountain ranges divide the country into the Pacific and Caribbean sides. These mountain ranges span southeast to northwest, and are of diverse ages and origins (Anderson and Timm 2006). Extending from western Panama to northern Costa Rica, the Cordillera de Talamanca, Cordillera Central, and Cordillera de Tilarán form an expansive mountain range with peak elevations of over 3,000, 2,500, and 2,000 masl, respectively. The Cordillera de Guanacaste is the northernmost range in Costa Rica, and is comprised of several isolated volcanoes, with passes of $\sim 500$ to 700 masl in elevation that connect the Pacific and Caribbean sides (Anderson and Timm 2006). The historical and current topography of these mountain ranges probably shaped the diversification and speciation patterns in the flora and fauna observable today.

The family Heteromyidae originated on the North America continent (Wood 1935; Schmidly et al. 1993), and fossil remains for the subfamily Heteromyinae are known from the Pliocene, Pleistocene, and Holocene (Rogers 1990). Rogers (1990) estimated that the major groups within this subfamily diverged $\sim 12$ to 13 mya, yet the historical events that produced the $H$. desmarestianus group are largely unknown. The geologic history of the Caribbean, and Central and South America has been a debated topic (Bartoli et al. 2005; Montes et al. 2012a, 2012b, 2015; Bacon et al. 2015; O'Dea et al. 2016), but it is thought that islands of volcanic origin between Central and South America may have allowed faunal exchanges prior to the formation of a permanent land bridge (Bartoli et al. 2005; Woodburne 2010; O'Dea et al. 2016). The time of the emergence of a permanent Panamanian land bridge is disputed, and estimates range from 2 to 7 mya (Montes et al. 2012b; but see Bacon et al.2015). Because of the widespread distribution pattern of the $H$. desmarestianus group, a hypothesis similar to the one suggested for other rodent groups has been proposed for this clade (Patterson and Pasqual 1972; Baskin 1978; Simpson 1980; Rogers 1990; Almendra and Rogers 2012; Pine et al. 2012); It is thought that considerable radiation occurred in the Miocene and Pliocene throughout Central America, with a subsequent entry to South America via the Panamanian land bridge (Rogers 1990; Schmidly et al. 1993).

Our results herein document a broad distribution of this distinct and unrecognized Costa Rican lowland lineage. The northern-most samples within this clade are from the Costa Rica-Nicaraguan border, while the southern-most are $\sim 86 \mathrm{~km}$ southeast of there. Unfortunately, little is known about spiny pocket mice in the lowlands of Nicaragua and south- ern Costa Rica, and we are unable to demarcate northern and southern boundaries of this mtDNA lineage. In terms of elevation, the lowland specimens came from forests that ranged in elevation from $\sim 22$ to 280 masl. In our analysis, we included a single GenBank sequence from Cerro Honduras in Parque Nacional Braulio Carrillo. The park, along with privately owned reserves and biological stations, is part of a continuously forested transect that expands from the lowlands at La Selva Biological Station and reaches elevations $>2,700$ masl. Although we do not have specific data on the elevation from which this particular specimen came, our results do show that this higher elevation specimen is a member of the clade with $\mathrm{H}$. desmarestianus proper from throughout Central America and does not group with our samples from the lowlands, including specimens from the nearby La Selva Biological Station. While our results suggest two distinct clades, we are unable to delineate at this time limits of their specific elevational range, or if there are areas of overlap or hybridization that await discovery.

Our results expand upon, compliment, and confirm Rogers and González (2010), who used both cytb and nuclear data, and identified three individuals from the Caribbean lowlands of Costa Rica as a potential candidate species. Although useful to characterize species that are difficult to establish based on morphological data, DNA sequence data do have limitations, particularly when a single marker is used (Farias et al. 2001; Rogers and González 2010). Now that we provide more extensive sampling of individuals from the Caribbean lowlands of Costa Rica, we recommend that future studies determine if population structure based on nuclear markers correlates with the distinctive mtDNA lineage of the Costa Rican lowland. Further investigation focused on nuclear DNA is also important because mitochondrial DNA and nuclear DNA can be discordant (Lack et al. 2010, Bernardo et al. 2019). This can result in distinct mitochondrial DNA lineages within a population or species that are not supported by nuclear DNA.

The diversity of rodent communities in the Caribbean lowlands of Costa Rica have been vastly understudied and we believe underestimated, in part, because of low densities resulting in low trap success (Romero, pers. obs.). Consequently, the lack of data and specimens has hindered our understanding of the basic phylogenetic relationships and biogeographic patterns of species in the area. Other widespread rodent species have been found to hold similar patterns reported herein, where individuals from the Caribbean lowlands of Costa Rica are genetically distinct and potentially new species (Timm, unpublished data). These data suggest that there may be significant cryptic diversity in the lowlands, and that more phylogenetic studies should include samples from this region to identify potential biogeographic patterns for rodents in the Neotropics. This information is necessary not only to understand phylogenetic relationships, but also to have a grasp on the patterns and levels of diversity for the area, and make largescale conservation decisions based on this information. We 
believe that our results, in conjunction with future studies that aim to identify and delineate diversity in the H. desmarestianus species complex, and the relationships between these species, will allow for a greater understanding of the historical events leading to speciation in this group.

Clearly much remains to be learned about the diversity of these widespread and common rodents that are considered keystone species in the Neotropics.

\section{Acknowledgments}

We thank D. McClearn, the Organization for Tropical Studies, and all of the landowners who supported our research. MINAET-SINAC and J. Guevara provided research permits. V. Weigand Noble, G. Fandos, and R. Garcia provided expert assistance in the field often under trying conditions. We thank A. Rinner, N. Marra, J. C. Patton, and O. F. Toro for generously sharing their expertise and support. Darrin Lunde, Suzanne Peurach, and Neal Woodman made specimens housed in the United States National Museum of Natural History, Washington, D. C. available to us and work in the collections productive.

\section{Literature Cited}

Almendra, A. L., and D. S. Rogers. 2012. Biogeography of Central American mammal: patterns and processes. Pp. 203-229 in Bones, clones, and biomes: the history and geography of Recent Neotropical mammals (Patterson, B. D., and L. P. Costa, eds.). University of Chicago Press. Chicago, U.S.A.

ANDERSON, R. P. 2003. Taxonomy, distribution, and natural history of the genus Heteromys (Rodentia: Heteromyidae) in western Venezuela, with the description of a dwarf species from the Península de Paraguaná. American Museum Novitates 3396:1-43.

ANDERSON, R. P. 2015. Family Heteromyidae. Pp. 51-58 in Mammals of South America, Volume 2: Rodents (Patton, J. L., U. F. J. Pardiñas, and G. D'Elía, eds.). University of Chicago Press. Chicago, U.S.A.

ANDERSON, R. P., AND E. E. GUtiérRez. 2009. Taxonomy, distribution, and natural history of the genus Heteromys (Rodentia: Heteromyidae) in central and eastern Venezuela, with the description of a new species from the Cordillera de la Costa. Pp. 33-93 in Systematic mammalogy: contributions in honor of Guy G. Musser. (Voss, R. S., and M. D. Carleton, eds.). Bulletin of the American Museum of Natural History 331.

Anderson, R. P., AND S. A. Jansa. 2007. Genetic comparisons between Heteromys desmarestianus and the recently described H. nubicolens (Rodentia: Heteromyidae) in northwestern Costa Rica. Mammalian Biology 72:54-61.

ANDERSON, R. P., AND P. JarRíN-V. 2002. A new species of spiny pocket mouse (Heteromyidae: Heteromys) endemic to western Ecuador. American Museum Novitates 3382:1-26.

ANDERSON, R. P., AND R. M. TIMm. 2006. A new montane species of spiny pocket mouse (Heteromyidae: Heteromys) from northwestern Costa Rica. American Museum Novitates 3509:1-38.

Anderson, R. P., M. WeKsLeR, And D. S. Rogers. 2006. Phylogenetic analyses of spiny pocket mice (Heteromyidae: Heteromyinae) based on allozymic and morphological data. Journal of Mammalogy 87:1218-1233.

Bacon, C. D., D. Silvestro, C. Jaramillo, B. T. SMith, P. Chakrabarty, AND A. ANTonelLI. 2015. Biological evidence supports an early and complex emergence of the Isthmus of Panama. Proceedings of the National Academy of Sciences 112:6110-6115.

Bartoli, G., M. Sarthein, M. Weinelt, H. Erlenkeuser, D. GarbeSCHÖNBERG, AND D. W. LEA. 2005. Final closure of Panama and the onset of northern hemisphere glaciation. Earth and Planetary Science Letters 237:33-44.

BASKIN, J. A. 1978. Bensonomys, Calomys, and the origin of the phyllotine group of Neotropical cricetines (Rodentia: Cricetidae). Journal of Mammalogy 59:125-135.

Beheregaray, L. B., AND A. Caccone. 2007. Cryptic biodiversity in a changing world. Journal of Biology 6:9.1-9.5.

Benson, D. A., M. Cavanaugh, K. Clark, I. Karsch-Mizrachi, D. J. Lipman, J. Ostell, and E. W. Sayers. 2013. GenBank. Nucleic Acids Research 41:36-42.

Bernardo, P. H., et AL. 2019. Extreme mito-nuclear discordance in a peninsular lizard: the role of drift, selection, and climate. Heredity: 1.

Bickford, D., D. J. Lohman, N. S. Sodhi, P. K. NG, R. Meier, K. Winker, K. K. InGRAM, AND I. DAs. 2007. Cryptic species as a window on diversity and conservation. Trends in Ecology and Evolution 22:148-155.

Bickham, J. W., J. C. Patton, D. A. Schlitter, I. L. Rautenbach, and R. L. HoNeYCUTT. 2004. Molecular phylogenetics, karyotypic diversity, and partition of the genus Myotis (Chiroptera: Vespertilionidae). Molecular Phylogenetics and Evolution 33:333-338.

Chave, J., G. Chust, and C. Thébaud. 2007. The importance of phylogenetic structure in biodiversity studies. Pp. 150-167 in Scaling biodiversity (Storch, D., P. L. Marquet, and J. H. Brown, eds.). Cambridge University Press. Cambridge, U.K.

Crandall, K. A., O. R. P. Bininda-Emonds, G. M. Mace, and R. K. Wayne. 2000. Considering evolutionary processes in conservation biology. TREE 15:290-295.

Crozier, R. H. 1992. Genetic diversity and the agony of choice. Biological Conservation 61:11-15.

Darriba, D., G. L. Taboada, R. Doallo, and D. Posada. 2012. jModelTest 2: more models, new heuristics and parallel computing. Nature Methods 9:772.

EDGAR, R. C. 2004. MUSCLE: multiple sequence alignment with high accuracy and high throughput. Nucleic Acids Research 32:1792-1797.

FAITH, D. P. 1992. Conservation evaluation and phylogenetic diversity. Biological Conservation 61:1-10.

Farias, I. P., G. Ortí, I. Sampalo, H. Schneider, and A. Meyer. 2001. The cytochrome $b$ gene as a phylogenetic marker: the limits of resolution for analyzing relationships among cichlid fishes. Journal of Molecular Evolution 53:89-103.

FLEMING, T. H. 1974. The population ecology of two species of Costa Rican heteromyid rodents. Ecology 55:493-510.

GoldmAn, E. A. 1911. Revision of the spiny pocket mice (genera Heteromys and Liomys). North American Fauna 34:1-70.

GraY, J. E. 1868. Synopsis of the species of Saccomyinae, or pouched mice in the collection of the British Museum. Proceedings of the Zoological Society of London 1868:199206. 
Guindon, S., And O. Gascuel. 2003. A simple, fast and accurate method to estimate large phylogenies by maximumlikelihood. Systematic Biology 52:696-704.

Hafner, J. C., J. E. Light, D. J. Hafner, M. S. Hafner, E. Reddington, D. S. Rogers, AND B. R. RiddLe. 2007. Basal clades and molecular systematics of heteromyid rodents. Journal of Mammalogy 88:1129-1145.

HaLl, E. R. 1981. The mammals of North America. John Wiley \& Sons, Inc. New York, U.S.A.

JANZEN, D. H. 1983. Costa Rican natural history. University of Chicago Press. Chicago, U.S.A.

Lack, J. B., J. E. Wilkinson, and R. A. Van Den Bussche. 2010. Range-wide population genetic structure of the pallid bat (Antrozous pallidus) -incongruent results from nuclear and mitochondrial DNA. Acta Chiropterologica 12:401-413.

MCCLEARN, D., ET AL. 2016. The Caribbean lowland evergreen moist and wet forests. Pp. 527-587 in Costa Rican ecosystems (M. Kappelle, ed.). University of Chicago Press. Chicago, U.S.A. Montes, C., ET AL. 2012a. Arc-continent collision and orocline formation: closing of the Central American seaway. Journal of Geophysical Research: Solid Earth 117(B4):1-25.

Montes, C., ET AL. 2012b. Evidence for middle Eocene and younger land emergence in central Panama: implications for isthmus closure. Bulletin of the Geological Society of America 124:780-799.

Montes, C., ET AL. 2015. Middle Miocene closure of the Central American Seaway. Science 348(6231):226-229.

MORT, M. E., ET AL. 2015. Multiplexed-shotgun-genotyping data resolve phylogeny within a very recently derived insular lineage. American Journal of Botany 102:634-641.

O'DeA, A., ET AL. 2016. Formation of the Isthmus of Panama. Science Advances 2(e1600883):1-11.

Patterson, B., and R. Pascual. 1972. The fossil mammal fauna of South America. Pp. 247-309 in Evolution, mammals, and southern continents (Keast, A., F. C. Erk, and B. Blass, eds.). State University of New York Press. Albany, U.S.A.

Patton, J. L. 2005. Family Heteromyidae. Pp. 844-858 in Mammal species of the world: a taxonomic and geographic reference (Wilson, D. E., and D. M. Reeder, eds.). 3rd edition. Johns Hopkins University Press. Baltimore, U.S.A.

Pine, R. H., R. M. TImm, ANd M. Weksler. 2012. A newly recognized clade of trans-Andean Oryzomyini (Rodentia: Cricetidae), with description of a new genus. Journal of Mammalogy 93:851-870.

Rambaut, A. 2007. FigTree. http://tree.bio.ed.ac.uk/software/ figtree. Accessed 13 February 2013.

REID, F. A. 2009. A field guide to the mammals of Central America \& Southeast Mexico. 2nd edition. Oxford University Press. New York, U.S.A.

Rogers, D. S. 1990. Genic evolution, historical biogeography, and systematic relationships among spiny pocket mice (subfamily Heteromyinae). Journal of Mammalogy 71:668685.

Rogers, D. S., AND M. W. González. 2010. Phylogenetic relationships among spiny pocket mice (Heteromys) inferred from mitochondrial and nuclear sequence data. Journal of Mammalogy 91:914-930.

Rogers, D. S., and D. J. Schmidly. 1982. Systematics of spiny pocket mice (genus Heteromys) of the desmarestianus species group from México and northern Central America. Journal of Mammalogy 63:375-386.

SAMBrook, J., E. FritsCH, AND T. Maniatis. 1989. Molecular cloning: a laboratory manual, 2nd edition. Cold Spring Harbor Laboratory Press. New York, U.S.A.

SChmidLY, D. J., K. T. WILKINS, AND J. N. DerR. 1993. Biogeography. Pp 319-356 in Biology of the Heteromyidae (Genoways, $\mathrm{H}$. H., and J. H. Brown, eds.). Special Publications 10, American Society of Mammalogists. Lawrence, U.S.A.

SIKES, R.S., ET AL. 2016. 2016 Guidelines of the American Society of Mammalogists for the use of wild mammals in research and education. Journal of Mammalogy 97:663-688.

SIMPSON, G. G. 1980. Splendid isolation: the curious history of South American mammals. Yale University Press. New Haven, U.S.A.

Sinclair, E. A., M. Pérez-Losada, and K. A. Crandall. 2005. Molecular phylogenetics for conservation biology. Pp. 19-56 in Phylogeny and conservation (Purvis, A., J. L. Glittleman, and T. Brooks, eds.). Cambridge University Press. Cambridge, U.K. TIMm, R. M., D. E. WILSON, B. L. Clauson, R. K. LaVaL, AND C. S. Vaughan. 1989. Mammals of the La Selva-Braulio Carrillo complex, Costa Rica. North American Fauna 75:1-162.

Waterhouse, A. M., J. B. Procter, D. M. A. Martin, M. Clamp, and G. J. BARTON. 2009. Jalview version 2-a multiple sequence alignments editor and analysis workbench. Bioinformatics 25:1189-1191.

Williams, D. F., H. H. Genoways, and J. K. Braun. 1993. Taxonomy. Pp. 38-196 in Biology of the Heteromyidae (Genoways, $\mathrm{H}$. H., and J. H. Brown, eds.). Special Publication 10, American Society of Mammalogists. Lawrence, U.S.A.

Wood, A. E. 1935. Evolution and relationships of the heteromyid rodents with new forms from the Tertiary of western North America. Annals of Carnegie Museum 24:73-262.

WoOdBURNE, M. O. 2010. The great American biotic interchange: dispersals, tectonics, climate, sea level and holding pens. Journal of Mammalian Evolution 17:245-264.

ZwICKL, D. J. 2006. Genetic algorithm approaches for the phylogenetic analysis of large biological sequence datasets under the maximum likelihood criterion. Dissertation, University of Texas. Austin, U.S.A.

Associated editor: Monica Díaz

Submitted: June 23, 2019; Reviewed: July 28, 2019;

Accepted: August 28, 2019; Published on line: September 16, 2019. 


\section{Appendix 1.}

Localities and specimen information for samples utilized in the study. Map numbers correspond to numbers on Figure 1. Data for specimens not from the Caribbean lowlands of Costa Rica were obtained from GenBank and the published papers associated with the GenBank accession numbers.

\begin{tabular}{|c|c|c|c|c|c|}
\hline Map & Species & Specimen information & GenBank & Locality & Country \\
\hline N/A & H. anomalus & $C M 78170=$ MDE $2087=$ AK 3468 & GU646919 & Miranda, 25 km N Altagracia de Orituco, $500 \mathrm{~m}$ & Venezuela \\
\hline$N / A$ & H. anomalus & CM 78168 = MDE 2034 = AK3437 & GU646924 & Sucre, 40 km NW Caripito, $250 \mathrm{~m}$ & Venezuela \\
\hline $40 a$ & H. australis & $\begin{array}{l}\text { LSUMZ } 35452=\text { MSH } 1187=\text { TK } \\
22565\end{array}$ & GU646926 & Darién, approximately 6 km NW Cana, E. slope Cerro Pirre, 1,200 m & Panama \\
\hline $40 \mathrm{~b}$ & H. australis & ROM 104356 = F38215 & GU646927 & Darién, Cerro Pirre, Parque Nacional Darién & Panama \\
\hline $8 a$ & H. desmarestianus & CM $91988=$ AK7663 & GU646929 & Stann Creek District, 3.4 km WNW Quam Bank, Cockscomb Basin & Belize \\
\hline $8 b$ & H. desmarestianus & $C M 91980=A K 7688$ & GU646930 & Stann Creek District, 6.8 km WNW Quam Bank, Cockscomb Basin & Belize \\
\hline $8 c$ & H. desmarestianus & CM $91951=$ AK 7665 & GU646932 & Stann Creek District, 7.7 km WNW Quam Bank, Cockscomb Basin & Belize \\
\hline $9 a$ & H. desmarestianus & CM $91991=$ AK 7540 & GU646933 & Toledo District, 1.0 km NNE Salamanca, Forestry Camp, Columbia Forest Reserve & Belize \\
\hline $9 b$ & H. desmarestianus & CM $91989=$ AK 7555 & GU646934 & Toledo District, 2.4 km NNW Salamanca, Forestry Camp, Columbia Forest Reserve & Belize \\
\hline $9 c$ & H. desmarestianus & CM $91993=$ AK 7588 & GU646935 & Toledo District; 2.1 km NNE Salamanca, Forestry Camp, Columbia Forest Reserve & Belize \\
\hline $9 c$ & H. desmarestianus & CM 91994 = AK 7586 & GU646936 & Toledo District; 2.1 km NNE Salamanca, Forestry Camp, Columbia Forest Reserve & Belize \\
\hline $9 c$ & H. desmarestianus & CM 91995 = AK 7589 & GU646937 & Toledo District; 2.1 km NNE Salamanca, Forestry Camp, Columbia Forest Reserve & Belize \\
\hline 18 & H. desmarestianus & KU $158615=$ MK 00-112 & DQ450094 & $\begin{array}{l}\text { Guanacaste, Area de Conservación Guanacaste, approximately } 20 \text { km NNE Liberia, } \\
\text { Pailas, Sendero Pailas, near Rio Colorado, } 800 \mathrm{~m}\end{array}$ & Costa Rica \\
\hline 17 & H. desmarestianus & KU $158508=$ MK 99-088 & DQ450095 & $\begin{array}{l}\text { Guanacaste: Área de Conservación Guanacaste, ca. } 39 \text { km N Liberia, Pitilla, Sendero } \\
\text { Orosilito }\end{array}$ & Costa Rica \\
\hline 17 & H. desmarestianus & KU $158509=$ MK 99-090 & DQ450096 & $\begin{array}{l}\text { Guanacaste: Área de Conservación Guanacaste, ca. } 39 \text { km N Liberia, Pitilla, Sendero } \\
\text { Orosilito }\end{array}$ & Costa Rica \\
\hline 17 & H. desmarestianus & KU $158512=$ MK 99-093 & DQ450097 & Guanacaste: Área de Conservación Guanacaste, ca. 39 km N Liberia, Pitilla & Costa Rica \\
\hline 17 & H. desmarestianus & KU $158513=$ MK 99-094 & DQ450098 & Guanacaste: Área de Conservación Guanacaste, ca. 39 km N Liberia, Pitilla & Costa Rica \\
\hline 17 & H. desmarestianus & KU $158514=$ MK 99-102 & DQ450099 & $\begin{array}{l}\text { Guanacaste: Área de Conservación Guanacaste, ca. } 39 \text { km N Liberia, Pitilla, Sendero } \\
\text { Carica }\end{array}$ & Costa Rica \\
\hline 22 & H. desmarestianus & ROM $113310=$ F 48617 & GU646938 & Alajuela; 10 km E of Sucre, Parque Nacional, Juan Costro Blanco & Costa Rica \\
\hline 22 & H. desmarestianus & ROM 113311 = F 48618 & GU646939 & Alajuela; 10 km E of Sucre, Parque Nacional, Juan Costro Blanco & Costa Rica \\
\hline 24 & H. desmarestianus & ROM 113130 = F 48436 & GU646940 & Cartago, Iztaru, Cerros de la Carpintera & Costa Rica \\
\hline 24 & H. desmarestianus & ROM 113131 = F 48437 & GU646941 & Cartago, Iztaru, Cerros de la Carpintera & Costa Rica \\
\hline 27 & H. desmarestianus & MVZ $164823=$ DSR 2153 & GU646942 & Cartago, Rio Reventazón, 5.6 km SE (by road) Turrialba, 450 m & Costa Rica \\
\hline 27 & H. desmarestianus & MVZ $164823=$ DSR 2154 & GU646943 & Cartago, Rio Reventazón, 5.6 km SE (by road) Turrialba, 450 m & Costa Rica \\
\hline 27 & H. desmarestianus & MVZ 164825 = DSR 2166 & GU646944 & Cartago, Rio Reventazón, 5.6 km SE (by road) Turrialba, 450 m & Costa Rica \\
\hline 27 & H. desmarestianus & MVZ 164826 = DSR 2167 & GU646945 & Cartago, Rio Reventazón, 5.6 km SE (by road) Turrialba, 450 m & Costa Rica \\
\hline 27 & H. desmarestianus & MVZ 164827 = DSR 2246 & GU646946 & Cartago, Rio Reventazón, 5.6 km SE (by road) Turrialba, 450 m & Costa Rica \\
\hline 26 & H. desmarestianus & ROM 97324 = FAR 111 & GU646947 & Cartago, $4 \mathrm{~km} \mathrm{SE}$ of Turrialba by road, Catie, $600 \mathrm{~m}$ & Costa Rica \\
\hline 26 & H. desmarestianus & ROM 97325 = FAR 112 & GU646948 & Cartago, $4 \mathrm{~km} \mathrm{SE}$ of Turrialba by road, Catie, $600 \mathrm{~m}$ & Costa Rica \\
\hline 20 & H. desmarestianus & MVZ $164828=$ DSR 2123 & GU646949 & Guanacaste, 4.1 km NE (by road) Tilarán, 650 m & Costa Rica \\
\hline 20 & H. desmarestianus & MVZ 164829 = DSR 2124 & GU646950 & Guanacaste, 4.1 km NE (by road) Tilarán, 650 m & Costa Rica \\
\hline 20 & H. desmarestianus & MVZ 164831 = DSR 2134 & GU646952 & Guanacaste, 4.1 km NE (by road) Tilarán, 650 m & Costa Rica \\
\hline 20 & H. desmarestianus & MVZ 164833 = DSR 2124 & GU646953 & Guanacaste, 4.1 km NE (by road) Tilarán, 650 m & Costa Rica \\
\hline 20 & H. desmarestianus & MVZ 164835 = DSR 2143 & GU646954 & Guanacaste, 4.1 km NE (by road) Tilarán, $650 \mathrm{~m}$ & Costa Rica \\
\hline 21 & H. desmarestianus & MVZ $164839=$ DSR 2121 & GU646955 & Guanacaste: 5.0 km NE (by road) Tilarán, 675 m & Costa Rica \\
\hline 21 & H. desmarestianus & MVZ $164840=$ DSR 2122 & GU646956 & Guanacaste: 5.0 km NE (by road) Tilarán, 675 m & Costa Rica \\
\hline 19 & H. desmarestianus & ROM 113244 = F 48551 & GU646957 & Guanacaste: Volcán Santa Maria & Costa Rica \\
\hline 19 & H. desmarestianus & ROM 113245 = F 48552 & GU646958 & Guanacaste: Volcán Santa Maria & Costa Rica \\
\hline 28 & H. desmarestianus & LSUMZ 28354 = MSH 1260 & GU646959 & Puntarenas, $1 \mathrm{~km} \mathrm{~N}, 5 \mathrm{~km}$ W Palmar Norte, $33 \mathrm{~m}$ & Costa Rica \\
\hline 25 & H. desmarestianus & BYU 15197 = EA 21 & GU646960 & San José, Bajo de Iglesia, SW Volcán Irazu, Cascajal de Coronado & Costa Rica \\
\hline 25 & H. desmarestianus & BYU $15198=$ EA 22 & GU646961 & San José, Bajo de Iglesia, SW Volcán Irazu, Cascajal de Coronado & Costa Rica \\
\hline 23 & H. desmarestianus & BYU $15195=$ EA 78 & GU646962 & San José, Parque Nacional Braulio Carillo, Moravia, Cerro Honduras & Costa Rica \\
\hline 23 & H. desmarestianus & BYU $15196=$ EA 79 & GU646963 & San José, Parque Nacional Braulio Carillo, Moravia, Cerro Honduras & Costa Rica \\
\hline
\end{tabular}


H. desmarestianus No specimen available

H. desmarestianus No specimen available

H. desmarestianus No specimen available

H. desmarestianus No specimen available

H. desmarestianus No specimen available

H. desmarestianus No specimen available

H. desmarestianus No specimen available

H. desmarestianus No specimen available

H. desmarestianus No specimen available

H. desmarestianus No specimen available

H. desmarestianus No specimen available

H. desmarestianus No specimen available

H. desmarestianus No specimen available

H. desmarestianus No specimen available

H. desmarestianus No specimen available

H. desmarestianus No specimen available

H. desmarestianus No specimen available

H. desmarestianus No specimen available

H. desmarestianus No specimen available

H. desmarestianus No specimen available

H. desmarestianus No specimen available

H. desmarestianus No specimen available

H. desmarestianus No specimen available

H. desmarestianus No specimen available

H. desmarestianus No specimen available

H. desmarestianus No specimen available

H. desmarestianus No specimen available

H. desmarestianus No specimen available

H. desmarestianus No specimen available

H. desmarestianus No specimen available

H. desmarestianus No specimen available

H. desmarestianus No specimen available

H. desmarestianus No specimen available

H. desmarestianus No specimen available

H. desmarestianus No specimen available

H. desmarestianus No specimen available

H. desmarestianus No specimen available

H. desmarestianus No specimen available

H. desmarestianus No specimen available

H. desmarestianus No specimen available

H. desmarestianus No specimen available

H. desmarestianus No specimen available

H. desmarestianus No specimen available

H. desmarestianus No specimen available

H. desmarestianus No specimen available

H. desmarestianus No specimen available

H. desmarestianus No specimen available

H. desmarestianus No specimen available

H. desmarestianus No specimen available

H. desmarestianus No specimen available

H. desmarestianus No specimen available

H. desmarestianus No specimen available
MN335341

MN335416

MN335415

MN335420

MN335369

MN335417

MN335429

MN335422

MN335368

MN335428

MN335344

MN335353

MN335356

MN335351

MN335379

MN335345

MN335412

MN335382

MN335405

MN335363

MN335404

MN335411

MN335403

MN335350

MN335389

MN335362

MN335383

MN335336

MN335381

MN335343

MN335387

MN335354

MN335386

MN335407

MN335359

MN335376

MN335391

MN335357

MN335361

MN335349

MN335399

MN335350

MN335355

MN335390

MN335380

MN335358

MN335384

MN335352

MN335342

MN335347

MN335340

MN335346

MN335392
Alajuela: Maquenque, $10^{\circ} 40^{\prime} 48.96^{\prime \prime} \mathrm{N}, 84^{\circ} 10^{\prime} 39.65^{\prime \prime} \mathrm{W}$

Costa Rica

Heredia: Selva Verde, $10^{\circ} 26^{\prime} 46.36^{\prime \prime} \mathrm{N}, 84^{\circ} 04^{\prime} 00.62^{\prime \prime} \mathrm{W}$

Costa Rica

Costa Rica

Costa Rica

Costa Rica

Costa Rica

Costa Rica

Costa Rica

Costa Rica

Costa Rica

Costa Rica

Costa Rica

Costa Rica

Costa Rica

Costa Rica

Costa Rica

Costa Rica

Costa Rica

Costa Rica

Costa Rica

Costa Rica

Costa Rica

Costa Rica

Costa Rica

Costa Rica

Costa Rica

Costa Rica

Costa Rica

Costa Rica

Costa Rica

Costa Rica

Costa Rica

Costa Rica

Costa Rica

Costa Rica

Costa Rica

Costa Rica

Costa Rica

Costa Rica

Costa Rica

Costa Rica

Costa Rica

Costa Rica

Costa Rica

Costa Rica

Costa Rica

Costa Rica

Costa Rica

Costa Rica

Costa Rica

Costa Rica

Costa Rica

Costa Rica 
H. desmarestianus

H. desmarestianus

H. desmarestianus

H. desmarestianus

H. desmarestianus

H. desmarestianus

H. desmarestianus

H. desmarestianus

H. desmarestianus

H. desmarestianus

H. desmarestianus

H. desmarestianus

H. desmarestianus

H. desmarestianus

H. desmarestianus

H. desmarestianus

H. desmarestianus

H. desmarestianus

H. desmarestianus

H. desmarestianus

H. desmarestianus

H. desmarestianus

H. desmarestianus

H. desmarestianus

H. desmarestianus

H. desmarestianus

H. desmarestianus

H. desmarestianus

H. desmarestianus

H. desmarestianus

H. desmarestianus

H. desmarestianus

H. desmarestianus

H. desmarestianus

H. desmarestianus

H. desmarestianus

H. desmarestianus

H. desmarestianus

H. desmarestianus

H. desmarestianus

H. desmarestianus

H. desmarestianus

H. desmarestianus

H. desmarestianus

H. desmarestianus

H. desmarestianus

H. desmarestianus

H. desmarestianus

H. desmarestianus

H. desmarestianus

H. desmarestianus

H. desmarestianus

ROM $99469=$ FN 32318
No specimen available

No specimen available

No specimen available

No specimen available

No specimen available

No specimen available

No specimen available

No specimen available

No specimen available

No specimen available

No specimen available

No specimen available

No specimen available

No specimen available

No specimen available

No specimen available

No specimen available

No specimen available

No specimen available

No specimen available

No specimen available

No specimen available

No specimen available

No specimen available

No specimen available

No specimen available

No specimen available

No specimen available

No specimen available

No specimen available

No specimen available

No specimen available

No specimen available

No specimen available

No specimen available

No specimen available

ROM $101369=$ F 35547

ROM $101389=$ F 35567

LVT 5499

ROM $98405=$ FN 31394

ROM 98406 = FN 31395

FN 31402

ROM $99603=$ FN 32272

ROM $99604=$ FN 32273

ROM 99292 = FN 31842

ROM 99293 = FN 31843

ROM 98266 = FN 31252

ROM $98265=$ FN 31254

TCWC $52259=$ BEL $865=$ AK 9696

MVZ $161229=$ DSR 1685

ROM $97050=$ FN 30853
MN335378 Heredia:Tirimbina, $10^{\circ} 24^{\prime} 45.58^{\prime \prime} \mathrm{N}, 84^{\circ} 07^{\prime} 02.55^{\prime \prime} \mathrm{W}$

Heredia: Tirimbina, $10^{\circ} 24^{\prime} 45.58^{\prime \prime} \mathrm{N}, 84^{\circ} 07^{\prime} 02.55^{\prime \prime} \mathrm{W}$

Heredia: Tirimbina, $10^{\circ} 24^{\prime} 45.58^{\prime \prime} \mathrm{N}, 84^{\circ} 07^{\prime} 02.55^{\prime \prime} \mathrm{W}$

Heredia: Tirimbina, $10^{\circ} 24^{\prime} 45.58^{\prime \prime} \mathrm{N}, 84^{\circ} 07^{\prime} 02.55^{\prime \prime} \mathrm{W}$

Heredia: Tirimbina, $10^{\circ} 24^{\prime} 45.58^{\prime \prime} \mathrm{N}, 84^{\circ} 07^{\prime} 02.55^{\prime \prime} \mathrm{W}$

Heredia: Tirimbina, $10^{\circ} 24^{\prime} 45.58^{\prime \prime} \mathrm{N}, 84^{\circ} 07^{\prime} 02.55^{\prime \prime} \mathrm{W}$

Heredia: Tirimbina, $10^{\circ} 24^{\prime} 45.58^{\prime \prime} \mathrm{N}, 84^{\circ} 07^{\prime} 02.55^{\prime \prime} \mathrm{W}$

Heredia: Tirimbina, $10^{\circ} 24^{\prime} 45.58^{\prime \prime} \mathrm{N}, 84^{\circ} 07^{\prime} 02.55^{\prime \prime} \mathrm{W}$

Heredia: Tirimbina, $10^{\circ} 24^{\prime} 45.58^{\prime \prime} \mathrm{N}, 84^{\circ} 07^{\prime} 02.55^{\prime \prime} \mathrm{W}$

Heredia: Tirimbina, $10^{\circ} 24^{\prime} 45.58^{\prime \prime} \mathrm{N}, 84^{\circ} 07^{\prime} 02.55^{\prime \prime} \mathrm{W}$

Heredia: Tirimbina, $10^{\circ} 24^{\prime} 45.58^{\prime \prime} \mathrm{N}, 84^{\circ} 07^{\prime} 02.55^{\prime \prime} \mathrm{W}$

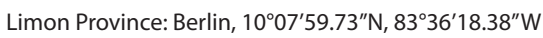

Limon Province: Berlin, $10^{\circ} 07^{\prime} 59.73^{\prime \prime} \mathrm{N}, 83^{\circ} 36^{\prime} 18.38^{\prime \prime} \mathrm{W}$

Limon Province: Berlin, 1007'59.73"N $83^{\circ} 36^{\prime} 18.38^{\prime \prime} \mathrm{W}$

MN335398

MN335409

MN335348

MN335334

MN335410

MN335402

MN33540

MN335333

MN335370

MN335414

MN335332

MN335413

MN335385

MN335393

MN335335

MN335375

MN335332

MN335419

MN335388

MN335360

MN335373

MN335374

MN335424

MN335418

GU646964

GU646965

AY926358

GU646966

GU646967

GU646968

GU646969

GU646970

GU646971

GU646973

GU646974

GU646975

GU646976

DQ168466

DQ168467

GU646977
Heredia: Agrícola Sofía, $10^{\circ} 27^{\prime} 32.01^{\prime \prime} \mathrm{N}, 83^{\circ} 58^{\prime} 41.40^{\prime \prime} \mathrm{W}$

Heredia: Agrícola Sofía, $10^{\circ} 27^{\prime} 32.01^{\prime \prime} \mathrm{N}, 83^{\circ} 58^{\prime} 41.40^{\prime \prime} \mathrm{W}$

Heredia: Agrícola Sofía, $10^{\circ} 27^{\prime} 32.01^{\prime \prime} \mathrm{N}, 83^{\circ} 58^{\prime} 41.40^{\prime \prime} \mathrm{W}$

Heredia: Agrícola Sofía, $10^{\circ} 27^{\prime} 32.01^{\prime \prime} \mathrm{N}, 83^{\circ} 58^{\prime} 41.40^{\prime \prime} \mathrm{W}$

Heredia: Agrícola Sofía, $10^{\circ} 27^{\prime} 32.01^{\prime \prime} \mathrm{N}, 83^{\circ} 58^{\prime} 41.40^{\prime \prime} \mathrm{W}$

Heredia: Agrícola Sofía, $10^{\circ} 27^{\prime} 32.01^{\prime \prime} \mathrm{N}, 83^{\circ} 58^{\prime} 41.40^{\prime \prime} \mathrm{W}$

Heredia: Agrícola Sofía, $10^{\circ} 27^{\prime} 32.01^{\prime \prime} \mathrm{N}, 83^{\circ} 58^{\prime} 41.40^{\prime \prime} \mathrm{W}$

Heredia: Agrícola Sofía, $10^{\circ} 27^{\prime} 32.01^{\prime \prime} \mathrm{N}, 83^{\circ} 58^{\prime} 41.40^{\prime \prime} \mathrm{W}$

Heredia: Agrícola Sofía, $10^{\circ} 27^{\prime} 32.01^{\prime \prime} \mathrm{N}, 83^{\circ} 58^{\prime} 41.40^{\prime \prime} \mathrm{W}$

Heredia: Starky, $10^{\circ} 26^{\prime} 31.73^{\prime \prime} \mathrm{N}, 83^{\circ} 59^{\prime} 09.16^{\prime \prime} \mathrm{W}$

Heredia: Starky, $10^{\circ} 26^{\prime} 31.73^{\prime \prime} \mathrm{N}, 83^{\circ} 59^{\prime} 09.16^{\prime \prime} \mathrm{W}$

Heredia: Starky, $10^{\circ} 26^{\prime} 31.73^{\prime \prime} \mathrm{N}, 83^{\circ} 59^{\prime} 09.16^{\prime \prime} \mathrm{W}$

Heredia: Starky, $10^{\circ} 26^{\prime} 31.73^{\prime \prime} \mathrm{N}, 83^{\circ} 59^{\prime} 09.16^{\prime \prime} \mathrm{W}$

Heredia: Starky, $10^{\circ} 26^{\prime} 31.73^{\prime \prime} \mathrm{N}, 83^{\circ} 59^{\prime} 09.16^{\prime \prime} \mathrm{W}$

Heredia: Starky, $10^{\circ} 26^{\prime} 31.73^{\prime \prime} \mathrm{N}, 83^{\circ} 59^{\prime} 09.16^{\prime \prime} \mathrm{W}$

Heredia: Starky, $10^{\circ} 26^{\prime} 31.73^{\prime \prime} \mathrm{N}, 83^{\circ} 59^{\prime} 09.16^{\prime \prime} \mathrm{W}$

Heredia: Starky, $10^{\circ} 26^{\prime} 31.73^{\prime \prime} \mathrm{N}, 83^{\circ} 59^{\prime} 09.16^{\prime \prime} \mathrm{W}$

Heredia: Starky, $10^{\circ} 26^{\prime} 31.73^{\prime \prime} \mathrm{N}, 83^{\circ} 59^{\prime} 09.16^{\prime \prime} \mathrm{W}$

Heredia: Starky, $10^{\circ} 26^{\prime} 31.73^{\prime \prime} \mathrm{N}, 83^{\circ} 59^{\prime} 09.16^{\prime \prime} \mathrm{W}$

Heredia: Starky, $10^{\circ} 26^{\prime} 31.73^{\prime \prime} \mathrm{N}, 83^{\circ} 59^{\prime} 09.16^{\prime \prime} \mathrm{W}$

Heredia: Starky, $10^{\circ} 26^{\prime} 31.73^{\prime \prime} \mathrm{N}, 83^{\circ} 59^{\prime} 09.16^{\prime \prime} \mathrm{W}$

Heredia: $10^{\circ} 26^{\prime} 03.92^{\prime \prime} \mathrm{N}, 84^{\circ} 07^{\prime} 42.76^{\prime \prime} \mathrm{W}$

Heredia: $10^{\circ} 26^{\prime} 03.92^{\prime \prime} \mathrm{N}, 84^{\circ} 07^{\prime} 42.76^{\prime \prime} \mathrm{W}$

Santa Ana, Parque Nacional Montecristi, Bosque Nebuloso, 2,200 m

Santa Ana, Parque Nacional Montecristi, Bosque Nebuloso, 2,200 m

Tikal, El Peten

Baja Verapaz: 5 km E of Puruhla, 1,550 m

Baja Verapaz: 5 km E of Puruhla, 1,550 m

Baja Verapaz: 5 km E of Puruhla, 1,550 m

El Peten: Biotope, Cerro Cahui, El Remate

El Peten: Biotope, Cerro Cahui, El Remate

El Peten: Campo los Guacamayos, Biotopo Laguna del Tigre, 40 km N El Naranjo

El Peten, Tikal

El Peten, Tikal

Sacatepequez, 5 km W San Miguel Duanas, 1,765 m

Sacatepequez, 5 km W San Miguel Duanas, 1,765 m

Atlántida, Lancetilla

Oaxaca; Distrito Ixtlán, Vista Hermosa, 1,000 m

Campeche, 10 km N El Refugio
Costa Rica

Costa Rica

Costa Rica

Costa Rica

Costa Rica

Costa Rica

Costa Rica

Costa Rica

Costa Rica

Costa Rica

Costa Rica

Costa Rica

Costa Rica

Costa Rica

Costa Rica

Costa Rica

Costa Rica

Costa Rica

Costa Rica

Costa Rica

Costa Rica

Costa Rica

Costa Rica

Costa Rica

Costa Rica

Costa Rica

Costa Rica

Costa Rica

Costa Rica

Costa Rica

Costa Rica

Costa Rica

Costa Rica

Costa Rica

Costa Rica

Costa Rica

Costa Rica

El Salvador

El Salvador

Guatemala

Guatemala

Guatemala

Guatemala

Guatemala

Guatemala

Guatemala

Guatemala

Guatemala

Guatemala

Guatemala

Honduras

Mexico

Mexico 


\begin{tabular}{|c|c|c|c|c|c|}
\hline 5 & H. desmarestianus & ROM 97051 = FN 30854 & GU646978 & Campeche, 10 km N El Refugio & Mexico \\
\hline 6 & H. desmarestianus & ROM 96089 = FN 29880 & GU646979 & Campeche: 25 km N Xpujil & Mexico \\
\hline 2 & H. desmarestianus & ASNHC $3515=$ LAF 1689 & GU646980 & Chiapas, 12 km N (by road) Berriozábal & Mexico \\
\hline 2 & H. desmarestianus & ASNHC $1424=$ ASK 660 & GU646981 & Chiapas, 12 km N (by road) Berriozábal & Mexico \\
\hline 2 & H. desmarestianus & ASNHC 1425 = ASK 689 & GU646982 & Chiapas, 12 km N (by road) Berriozábal & Mexico \\
\hline $4 a$ & H. desmarestianus & ASNHC $1426=$ ASK 51 & GU646983 & Chiapas, 6.6 km S Palenque & Mexico \\
\hline $4 b$ & H. desmarestianus & ASNHC $5826=$ ASK 49 & GU646984 & Chiapas, $9.0 \mathrm{~km}$ S Palenque & Mexico \\
\hline $4 c$ & H. desmarestianus & ROM 96096 = FN 29887 & GU646985 & Chiapas, $12.5 \mathrm{~km}$ S Palenque & Mexico \\
\hline $4 c$ & H. desmarestianus & ROM 96105 = FN 29896 & GU646986 & Chiapas, $12.5 \mathrm{~km}$ S Palenque & Mexico \\
\hline $4 d$ & H. desmarestianus & ASNHC $1440=$ ASK 29 & GU646987 & Chiapas, 1.2 km E Ruinas de Palenque & Mexico \\
\hline $4 d$ & H. desmarestianus & ASNHC 1441 = ASK 31 & GU646988 & Chiapas, 1.2 km E Ruinas de Palenque & Mexico \\
\hline $3 a$ & H. desmarestianus & ROM $97542=$ FN 33018 & GU646989 & Chiapas, $6 \mathrm{~km}$ E of Rayon, 1,560 m & Mexico \\
\hline $3 b$ & H. desmarestianus & ASNHC 1431 = ASK 589 & GU646990 & Chiapas, 9 km SE Rayon & Mexico \\
\hline $3 b$ & H. desmarestianus & ASNHC 1432 = ASK 591 & GU646991 & Chiapas, 9 km SE Rayon & Mexico \\
\hline 7 & H. desmarestianus & ROM $97520=$ FN 30995 & GU646992 & Quintana Roo, 1 km N Noh-Bec & Mexico \\
\hline 7 & H. desmarestianus & ROM 97521 = FN 30996 & GU646993 & Quintana Roo, 1 km N Noh-Bec & Mexico \\
\hline $1 b$ & H. desmarestianus & $C M 79530=$ DSR $934=$ AK 3108 & GU646994 & Oaxaca, Vista Hermosa, 1,000 m & Mexico \\
\hline $1 b$ & H. desmarestianus & MVZ $161230=$ DSR 1686 & GU646995 & Oaxaca; Distrito Ixtlán, Vista Hermosa, 1,000 m & Mexico \\
\hline 16 & H. desmarestianus & ROM $112284=$ F 48170 & GU646996 & Esteli, Esteli & Nicaragua \\
\hline 39 & H. nelsoni & BYU $20644=$ DSR 7189 & GU647014 & Chiapas, Cerro Mozotal, $15^{\circ} 25.866^{\prime} \mathrm{N}, 92^{\circ} 20.274^{\prime} \mathrm{W}, 2,930 \mathrm{~m}$ & Panama \\
\hline
\end{tabular}

